\title{
Pitvarfibrilláció abláció indikációi és stroke- prevenció a 2016-os új ESC ajánlások tükrében
}

\author{
Nagy Klaudia Vivien, Szegedi Nándor, Gellér László
}

Semmelweis Egyetem, Városmajori Szív- és Érgyógyászati Klinika, Budapest

Levelezési cím: Dr. Nagy Klaudia Vivien, 1122 Hungary, Városmajor u. 68. E-mail: nagyklaudiavivien@gmail.com

A pitvarfibrilláció modern terápiájában az elmúlt években jelentős fejlődés következett be, mind a tromboembóliás rizikó csökkentése, mind pedig a ritmuszavar definitív kezelése terén. Jelen összefoglalónkban röviden, a lényegi elemeket kiemelve áttekintettük az Európai Kardiológus Társaság (ESC) legújabb ajánlásait a pitvarfibrilláció kezelésére.

Kulcsszavak: pitvarfibrilláció, irányelv, antikoaguláció, ritmuskontroll, katéterabláció

Novel indications of ablation and stroke prevention in atrial fibrillation according to the most recent ESC guidelines Despite the rapid progress in the management of patients with atrial fibrillation, this remains one of the major causes of stroke, heart failure, sudden death, and cardiovascular morbidity worldwide. Furthermore, the number of patients with $\mathrm{AF}$ is predicted to rise significantly in the upcoming years. Our aim was to review the latest guidelines of the European Society of Cardiology (ESC) and highlight the most important messages about the treatment of atrial fibrillation.

Keywords: atrial fibrillation, guideline, anticoagulation, rhythm control, catheter ablation

\section{Bevezetés}

A pitvarfibrilláció (PF) a leggyakoribb tartós ritmuszavar, amelynek klinikai jelentősége kiemelkedő. Kezelésében jelentős fejlődés történt az utóbbi 10 évben, azonban jelenleg is a leggyakrabban stroke-ot, szívelégtelenséget, hirtelen halált, kardiovaszkuláris morbiditást okozó aritmia. Prevalenciája 20 évnél idősebb felnőttekben 3\% körül mozog, gyakorisága tovább növekszik az életkor elörehaladtával, továbbá hipertónia, szívelégtelenség, koronária-, illetve billentyübetegség, obesitas és krónikus vesebetegség jelenléte mellett (1). A pitvarfibrilláló betegek száma az elkövetkező években tovább fog nőni Európában, 2030-ra 14-17 millió pitvarfibrilláló beteget jósolnak, évente 120-250 ezer frissen diagnosztizált esettel (2). Sok kardiovaszkuláris betegség és állapot növeli a PF kialakulásának, visszatérésének és PF-hez kötődő komplikációk kialakulásának kockázatát. Ezek felismerése és kezelése nagyon fontos tényező a PF-rekurrenciák megelőzésében. Ezért minden pitvarfibrilláló beteg esetében fontos a részletes anamnézisfelvétel, a tünetek és panaszok kikérdezése, beleértve a PF legygyakoribb szövődményeinek, így tromboembóliás események és balkamra-diszfunkció felmérését is (3).
Az Európai Kardiológus Társaság ajánlásaiban az egyes kezelési lehetőségekre vonatkozó adatok bizonyító erejét, valamint az ajánlások erejét elöre meghatározott skálák alapján súlyozza és rangsorolja, amint azt az 1. és 2. táblázat is szemlélteti.

\section{Stroke-prevenció pitvarfibrilláló betegekben}

Pitvarfibrilláló betegekben az orális antikoaguláns kezelés (OAC) a stroke rizikóját harmadára csökkenti, továbbá szignifikánsan javítja az életkilátásokat (4). Ezért csaknem minden beteget antikoagulálni szükséges, amely alól kivételt képeznek az igen alacsony stroke-rizikóval rendelkezők. Ennek ellenére sok esetben nem alkalmaznak OAC-ot, amelynek leggyakoribb okai a minor és major vérzések, magasnak vélt vérzéses rizikó és a K-vitamin-antagonista (VKA) kezelés mellett szükséges rendszeres laborvizsgálat nehezítettsége. Azonban az OAC nélkül jelen lévő stroke-rizikó gyakran magasabb a vérzéses rizikónál. Trombocitaaggregáció-gátló (aszpirin) kezelés mellett a vérzéses rizikó nem különbözik az OAC-kezelés melletti rizikótól, azonban az ASA stroke-prevencióra nem alkalmas, 


\section{A TÁBLÁZAT. Az ajánlások osztályozása}

\section{Az ajánlások osztályozása}

I. osztály

II. osztály

Ila osztály

Ilb osztály

III. osztály

\section{Meghatározás}

Az adatok alátámasztják és/vagy általános az egyetértés arra vonatkozóan, hogy az adott kezelés vagy eljárás kedvező hatású, hasznos és hatásos.

Az adott kezelés vagy eljárás hasznosságával/hatásosságával kapcsolatban ellentmondásos adatok és/vagy véleménykülönbségek léteznek.

Az adatok/vélemények többsége a hasznosság/hatásosság mellett szól.

Az adatok/vélemények kevésbé támasztják alá a hasznosságot/hatásosságot.

Az adatok alátámasztják és/vagy általános az egyetértés arra vonatkozóan, hogy az adott kezelés/eljárás nem hasznos/hatásos, és hogy esetenként káros lehet.

\section{Javasolt alkalmazás} megfogalmazása

Ajánlott/indikált

Megfontolandó

Megfontolható

Nem ajánlott

1. B TÁBLÁZAT. Az ajánláshoz használt adatok bizonyító ereje

\begin{tabular}{l|l} 
„A" szintủ adatok & Több randomizált klinikai vizsgálat vagy metaanalízis alapján kapott adatok. \\
„B" szintű adatok & Egy randomizált klinikai vizsgálat vagy nagy, nem randomizált vizsgálatok alapján kapott adatok. \\
"C szintű adatok & A szakértők és/vagy kisebb vizsgálatok, retrospektív vizsgálatok, felmérések közötti konszenzus.
\end{tabular}

így annak alkalmazása pitvarfibrilláló betegekben nem ajánlott (IIIA). Kivételt képez ez alól természetesen, ha a páciensnek egyéb indikációja (pl. korábbi koronáriaintervenció) van ASA szedésére.

A stroke-rizikó becslésére $\mathrm{CHA}_{2} \mathrm{DS}_{2}$-VASc score rendszer (2. táblázat) használatos, amelynek alapján férfiak esetében, ha értéke $\geq 2$, illetve nők esetében $\geq 3$ a beteget antikoagulálni kell (IA). Amennyiben férfiaknál $\geq 1$, nőknél $\geq 2$ az érték, az OAC-kezelés megfontolandó (Ila/B). Korábban stroke-rizikó faktorként szereplő női nem az új ESC-ajánlások alapján nem növeli a stroke rizikóját.

Korábban a vérzéses rizikó becslésére használt score rendszerek (HAS-BLED, ORBIT, ABC) alkalmazása továbbiakban nem javasolt, mivel a stroke és a vérzéses rizikófaktorok - mint például a magasabb életkor - egymást átfedik. A magas vérzéses rizikó általánosságban nem vezethet OAC-kezelés megvonásához.

A tromboembóliás rizikó csökkentése céljából elvégezhető a bal pitvari fülcse intervenciós, illetve sebészi úton történő zárása. Intervenció esetén alkalmazott eszköz (Watchman ${ }^{\odot}$, 1. ábra) a randomizált vizsgálatok alapján stroke-prevenció tekintetében non-inferior volt a VKA-kezeléssel összehasonlítva $(5,6)$. Alkalmazása azon betegekben javasolt, akiknél antikoaguláns keze-

\begin{tabular}{|c|c|}
\hline $\mathrm{CHA}_{2} \mathrm{DS}_{2}$-VASc score & Pontszám \\
\hline Szívelégtelenség & +1 \\
\hline Hipertónia & +1 \\
\hline Életkor $\geq 75$ év & +2 \\
\hline Diabetes mellitus & +1 \\
\hline Korábbi stroke, vagy TIA & +2 \\
\hline Érbetegség (koronária, perifériás) & +1 \\
\hline Életkor 65-74 év & +1 \\
\hline Női nem & +1 \\
\hline
\end{tabular}

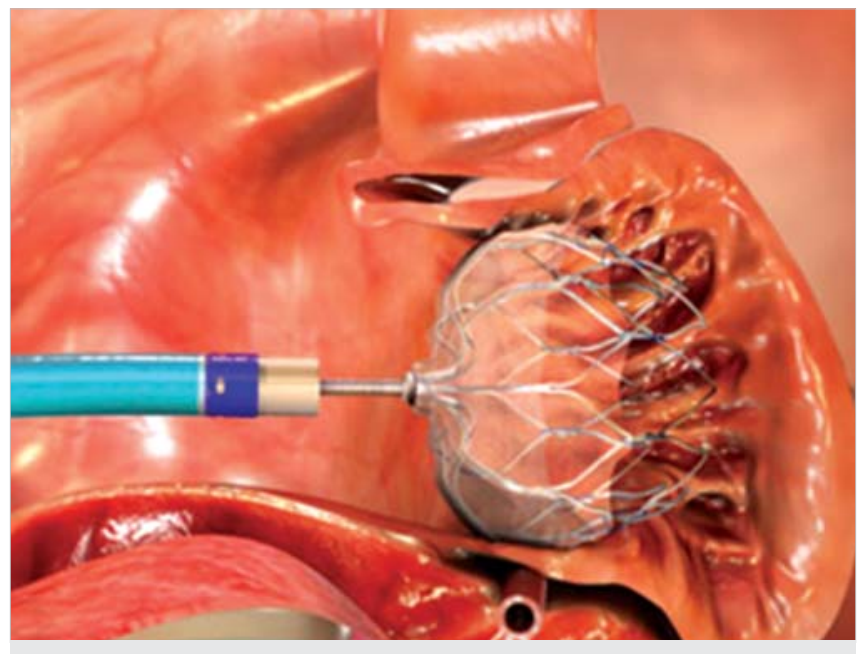

1. ÁBRA. Perkután fülcsezárás Watchmann ${ }^{\odot}$-eszköz segítségével

lés kontraindikációja áll fenn (Ilb/B). Sebészi fülcsezárás megfontolandó minden PF-es betegnél, aki más ok miatt szívsebészeti mútéten esik át (Ilb/B). Ezen betegekben antikoaguláns kezelés, amennyiben kontraindikációja nem áll fenn, folytatandó fülcsezárást követően is (IB).

\section{Pitvarfibrilláció hosszú távú ritmuskontrollja}

Célja a PF tüneteinek csökkentése. Általánosságban az antiaritmiás szerek (Propafenon, Amiodaron, Sotalol) közepesen hatékonyak sinusritmus fenntartására (7). Megfelelő módszer kiválasztása előtt mérlegelni kell a tünetek súlyosságát, lehetséges mellékhatásokat és a beteg preferenciáit. Legfontosabb szempont a biztonság, ezért amennyiben lehetséges, rövid távú antiaritmiás kezelésre kell törekednünk. Emellett egyéb, primeren nem antiaritmiás szereknek is van sinusritmus fenntartó hatásuk. Így balkamra-diszfunkció, hiper- 


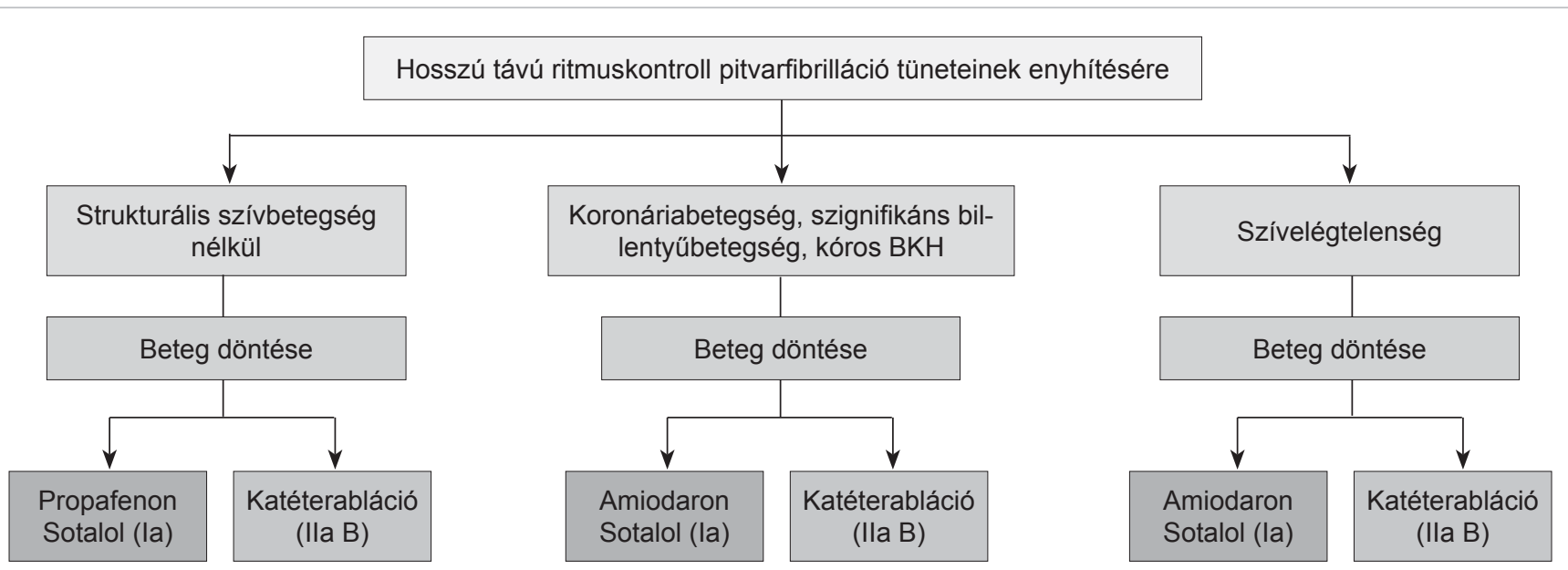

2. ÁBRA. Hosszú távú ritmuskontroll sémája tünetes pitvarfibrillációban az új ESC-ajánlás alapján. BKH: balkamra-hipertrófia

tónia, balkamra-hipertrófia esetén ACE-inhibitorok, ARB-k, illetve béta-blokkoló alkalmazása csökkenti új keletű PF kialakulásának gyakoriságát. Krónikus ritmuskontroll új ESC-ajánlás alapján elkészített sémáját a 2. ábra tartalmazza.

\section{PF katéterablációja}

Transzkatéteres beavatkozás során a PF kialakulásáért és fenntartásáért ismerten felelős pulmonalis vénák szájadékát elektromosan izoláljuk (PVI) a bal pitvar többi részétől (8). Gyakorlott centrumokban alkalmazása jelentősen hatékonyabb a sinusritmus fenntartására az antiaritmiás gyógyszeres kezelésnél, hasonló szövődményráta mellett $(9,10)$.

\section{Indikáció}

PF-abláció a legújabb ajánlások szerint IA indikációval szerepel tünetes paroxizmális PF esetén, amenynyiben antiaritmiás gyógyszeres kezelés nem hatékony a tünetek enyhítésére és az SR fenntartására. Továbbá első választandó kezelésként alkalmazható paroxizmális PF-es, antiaritmiás kezelésben nem részesülő betegekben, a PF-rekurrencia megelőzésére a beteg egyéni preferenciája alapján (Ila/B). Perzisztens és long-standing perzisztens, gyógyszeres kezelésre refrakter $P F$ esetén is elvégezhető a tünetek enyhítésére, mérlegelve a rizikó-haszon arányt, a beteg és a kezelőorvos döntése alapján (Ila/C). Emellett csökkent balkamra-funkciójú, szívelégtelen, tünetes pitvarfibrilláló betegekben is javasolt a tünetek és a balkamra-funkció javítására (Ila/C) (3. táblázat).

\section{Technikák}

A PF-abláció elsődleges célpontja a pulmonalis vénák (PV) komplett izolációja. Háromdimenziós térképező rendszer segítségével $\left(\mathrm{CARTO}^{\odot}\right.$, EnSite $^{\odot}$, Rhythmia $^{\odot}$ ) elektroanatómiai térképet készítünk a bal pitvar üregéről, amelyet a betegről a beavatkozást megelőzően végzett bal pitvari CT-angiográfiás képpel kombinálva valós időben, pontos 3D-képet kapunk a bal pitvar üregéről (3. $b$ ábra).

$P V I$ végzésére három technika terjedt el:

- rádiofrekvenciás (RF) energiával pontról-pontra (3. ábra).

- Cirkuláris RF-katéter segítségével (PVAC) (4. ábra).

- Cryoenergiával, cryoballon segítségével történő PVI (5. ábra).

A FIRE AND ICE randomizált klinikai vizsgálat eredménye alapján paroxizmális PF ablációs kezelésére a point by point RF-technika és a cryoballonos abláció hatékonysága megegyezik (11).

3. TÁBLÁZAT. Pitvarfibrilláció ablációra vonatkozó legújabb ESC-ajánlások

\section{Ajánlás}

$P V I$ javasolt PF tüneteinek enyhítésére antiaritmiás kezelés ellenére visszatérő paroxizmális PF esetén.

Osztály Szint

$\mathrm{PVI}$ első választandó kezelésként javasolt paroxizmális PF esetén a tünetek enyhítésére és a rekurrencia megelőzése céljából antiaritmiás gyógyszeres kezelés helyett, válogatott betegcsoportban, egyéni preferenciák alapján.

$P V I$ végzése mérlegelendő antiaritmiás gyógyszeres kezelés ellenére fennálló perzisztens és long-standing perzisztens PF esetén a tünetek enyhítésére mérlegelve a rizikót és az elönyöket.

$P V I$ végzése megfontolandó tünetes pitvarfibrilláló, szívelégtelen, csökkent balkamra-funkcióval rendelkező betegekben a tünetek enyhítésére és a szívfunkció javítására, továbbá amennyiben tachycardiomyopathia jelenléte felmerül. 

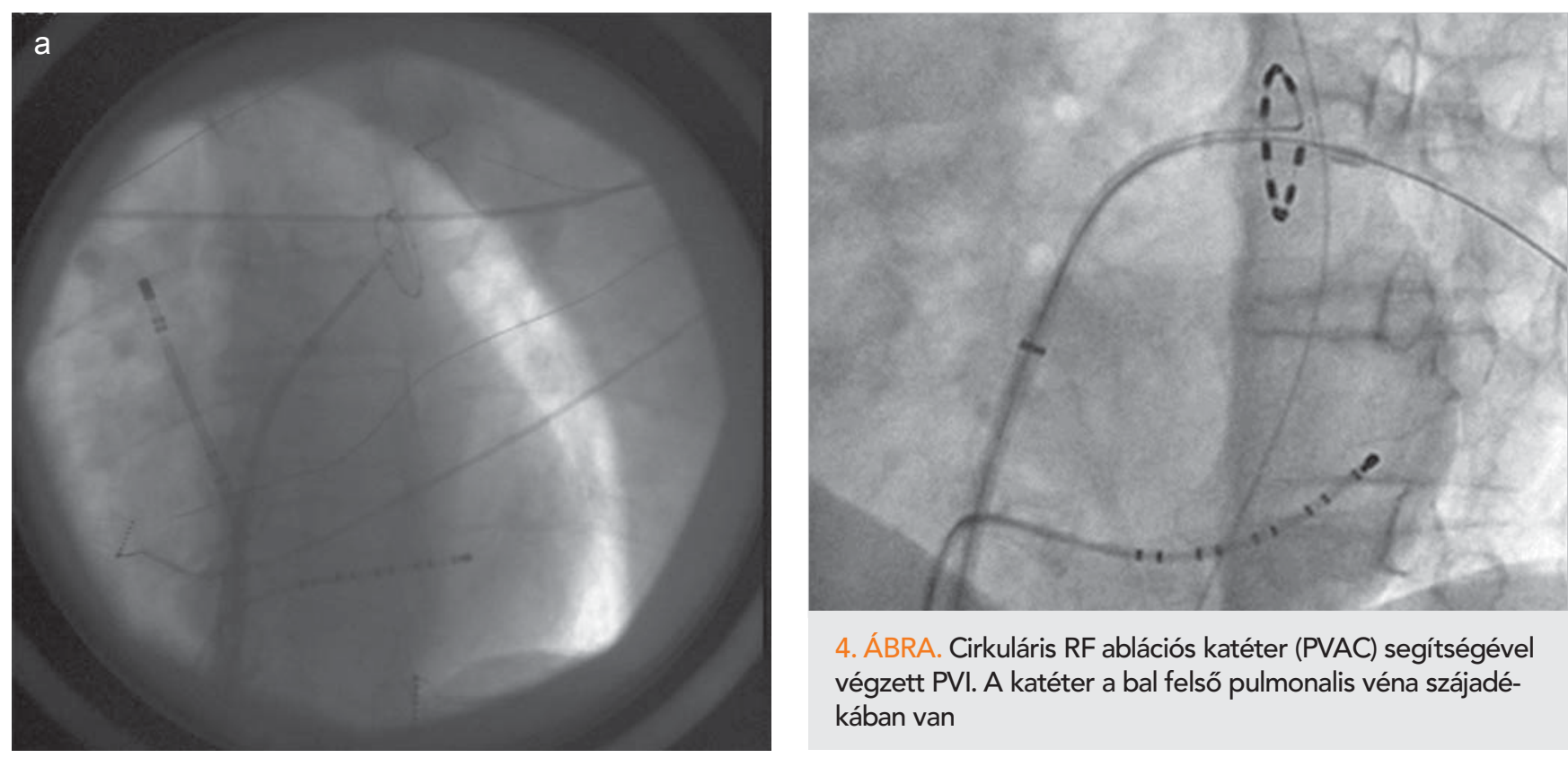

4. ÁBRA. Cirkuláris RF ablációs katéter (PVAC) segítségével végzett PVI. A katéter a bal felső pulmonalis véna szájadékában van
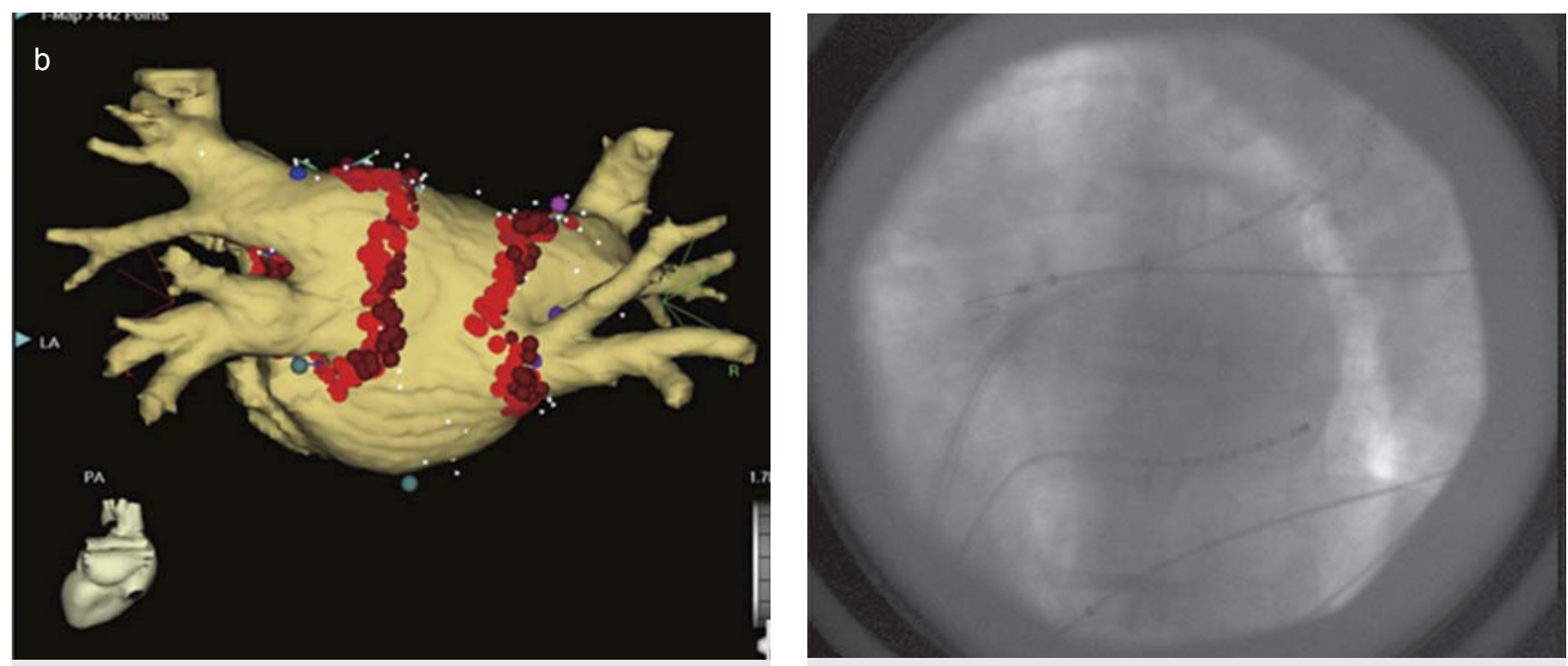

3. a ÁBRA. Fluoroszkópiás felvétel point by point RF-ablációról, Lasso-katéter a bal felső pulmonalis vénában, ablációs katéter a jobb felső pulmonalis vénában helyezkedik el, b ÁBRA: CARTO ${ }^{\odot}$-rendszer segítségével készült bal pitvari elektroanatómiai térkép és ablációs pontok (piros)

Perzisztens PF esetén is elsődleges célpont a PV-izoláció. A 2015-ben publikált STAR AF II randomizált vizsgálat eredménye alapján a bal pitvarban addicionális léziók létrehozása (roofline, mitralis isthmus, anterior vonal, box technika, CFAE, rotor) az első abláció sikerarányát nem, azonban a procedúra időt és a sugárdózist növeli (12). Ismételt abláció esetén azonban PV-izoláció mellett addicionális technikák alkalmazása szükséges lehet a sinusritmus fenntartására (13). Azon betegekben, akiknél EKG-n dokumentált típusos jobb pitvari flutter is jelen van, isthmus-abláció végzése szükséges (Ila/B). Az úgynevezett rotor-abláció jelenleg kísérleti fázisban van, így még nem ajánlható a rutin klinikai alkalmazásra.

5. ÁBRA. Második generációs cryoballon segítségével végzett PVI, a felfújt cryoballon a bal felső pulmonalis vénában helyezkedik el

\section{Kimenetel és szo̊vődmények}

Katéterabláció az antiaritmiás kezelésnél hatékonyabb módszer a sinusritmus fenntartására. Irodalmi adatok alapján PVI sikeraránya paroxizmális PF esetén $70 \%$, perzisztens PF esetén $50 \%$ körül mozog (14). A betegek egy részénél reabláció végzése szükséges. Az évek múltán jelentkező késői PF-rekurrencia viszonylag gyakori jelenség és inkább a betegség progressziójával hozható összefüggésbe (15).

Irodalmi adatok alapján a betegek 5-7\%-a esetében lép fel major szövődmény, 2-3\%-ban jelentkezik életet veszélyeztető, de az esetek döntő többségében jól kezel- 

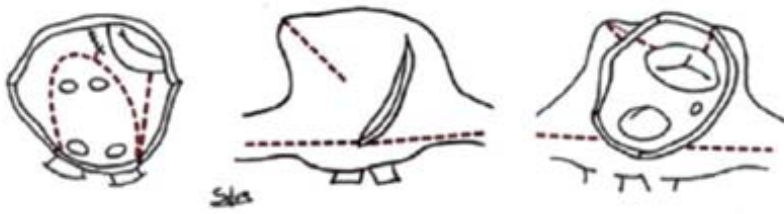

6. ÁBRA. Cox maze műtét során készített sebészi ablációs vonalak a bal (bal oldali panel) és a jobb (középső és jobb oldali panel) pitvarban

hető komplikáció (16). Leggyakoribb akut szövődmények a stroke/TIA (<1\%) és a tamponád (1-2\%). Az úgynevezett „silent stroke” nagy vizsgálatok eredménye alapján a betegek kb. 10\%-ában volt kimutatható koponya MR-vizsgálat segítségével, azonban ezek klinikai jelentősége egyelőre nem ismert (17). Középtávon (3-4 héttel abláció után) jelentkező, igen ritka, életet veszélyeztető szövődmény az atrio-oesophagealis fisztula kialakulása. Késői, szintén igen ritka komplikáció a PV-stenosis, amely megelőzhető antrális abláció végzésével.

\section{Pitvarfibrilláció sebészi ablációja}

30 évvel ezelőtt végezték először a biatrialis Cox maze mütétet, ennek során a pulmonalis vénákat közösen izolálták a bal pitvar többi részétől, amelyet a bal pitvari fülcse lekötésével egészíttettek ki (6. ábra) (18). Biatrialis Cox maze mütét végzése azon betegcsoportban javasolt PF tüneteinek enyhítésére, akiknél egyéb okból nyitott szívmütétre van szükség (Ila/A).

\section{Következtetések}

Mivel PF igen gyakori és potenciálisan súlyos szövődményekkel járó ritmuszavar, ezért minél előbbi felismerése és megfelelő kezelése rendkívül fontos. PF-re magas rizikójú betegekben EKG-szürés elengedhetetlen. Emellett a magas stroke-kockázattal rendelkező PF-es betegeket antikoagulálni szükséges még akkor is, ha a vérzéses rizikó is magasabbnak bizonyul. Az új, 2016os szakmai irányelv kiemeli a vérzéses rizikót fokozó, potenciálisan reverzibilis kockázati tényezők korrekcióját, pl. kontrollálatlan hipertónia, beszúkült vesefunkció, anémia, nagymennyiségú alkoholfogyasztás stb. Fontos továbbá a társbetegségek, így például hipertónia és szívelégtelenség időben történő felismerése és megfelelő kezelése. Emellett a PF terápiája a beteg individuális jellemzői és személyes preferenciái alapján történjen, beleértve a megfelelő frekvencia- és ritmuskontrollt, amely magában foglalja a PF ablációs kezelését is.

\section{Irodalom}

1. Chugh SS, Havmoeller R, Narayanan K, Singh D, Rienstra M, Benjamin EJ, et al. Worldwide epidemiology of atrial fibrillation: a Global Burden of Disease 2010 Study. Circulation 2014; 129(8): 837-47. DOI: 10.1161/CIRCULATIONAHA.113.005119
2. Krijthe BP, Kunst A, Benjamin EJ, Lip GY, Franco OH, Hofman A et al. Projections on the number of individuals with atrial fibrillation in the European Union, from 2000 to 2060. Eur Heart J 2013; 34(35): 2746-51. DOI: 10.1093/eurheartj/eht280

3. Kirchhof P, Benussi S, Kotecha D, Ahlsson A, Atar D, Casadei B, et al. 2016 ESC Guidelines for the management of atrial fibrillation developed in collaboration with EACTS. Europace 2016; 18(11): 1609-78. DOI: 10.1093/europace/euw295

4. Hart RG, Pearce LA, Aguilar MI. Meta-analysis: antithrombotic therapy to prevent stroke in patients who have nonvalvular atrial fibrillation. Ann Intern Med 2007; 146(12): 857-67.

5. Holmes DR, Kar S, Price MJ, Whisenant B, Sievert H, Doshi SK, et al. Prospective randomized evaluation of the Watchman Left Atrial Appendage Closure device in patients with atrial fibrillation versus long-term warfarin therapy: the PREVAIL trial. J Am Coll Cardiol 2014; 64(1): 1-12. DOI:10.1016/j.jacc.2014.04.029

6. Reddy VY, Doshi SK, Sievert H, Buchbinder M, Neuzil P, Huber $\mathrm{K}$, et al. Percutaneous left atrial appendage closure for stroke prophylaxis in patients with atrial fibrillation: 2.3-Year Follow-up of the PROTECT AF (Watchman Left Atrial Appendage System for Embolic Protection in Patients with Atrial Fibrillation) Trial. Circulation 2013; 127(6): 720-9, DOI: 10.1161/CIRCULATIONAHA.112.114389 7. Lafuente-Lafuente C, Longas-Tejero MA, Bergmann JF, Belmin J. Antiarrhythmics for maintaining sinus rhythm after cardioversion of atrial fibrillation. Cochrane Database Syst Rev 2012(5): CD005049, DOI: 10.1002/14651858.CD005049.pub3

8. Haî́ssaguerre M, Jaïs P, Shah DC, Takahashi A, Hocini M, Quiniou $\mathrm{G}$, et al. Spontaneous initiation of atrial fibrillation by ectopic beats originating in the pulmonary veins. N Engl J Med 1998; 339(10): 659-66. DOI: 10.1056/NEJM199809033391003

9. Mont L, Bisbal F, Hernández-Madrid A, Pérez-Castellano N, Viñolas X, Arenal A, et al. Catheter ablation vs. antiarrhythmic drug treatment of persistent atrial fibrillation: a multicentre, randomized, controlled trial (SARA study). Eur Heart J 2014; 35(8): 501-7. DOI: 10.1093/eurheartj/eht457

10. Cosedis Nielsen J, Johannessen A, Raatikainen P, Hindricks G, Walfridsson $\mathrm{H}$, Kongstad $\mathrm{O}$, et al. Radiofrequency ablation as initial therapy in paroxysmal atrial fibrillation. N Engl J Med 2012; 367(17): 1587-95. DOI: 10.1056/NEJMoa1113566

11. Kuck KH, Brugada J, Fürnkranz A, Metzner A, Ouyang F, Chun $K R$, et al. Cryoballoon or Radiofrequency Ablation for Paroxysmal Atrial Fibrillation. N Engl J Med 2016; 374(23): 2235-45. DOI: 10.1056/NEJMoa1602014

12. Verma A, Macle L, Sanders P. Catheter Ablation for Persistent Atrial Fibrillation. N Engl J Med 2015; 373(9): 878-9. DOI: 10.1056 NEJMc1508689

13. Scherr D, Khairy P, Miyazaki S, Aurillac-Lavignolle V, Pascale $P$, Wilton SB, et al. Five-year outcome of catheter ablation of persistent atrial fibrillation using termination of atrial fibrillation as a procedural endpoint. Circ Arrhythm Electrophysiol 2015; 8(1): 18-24. DOl: 10.1161/CIRCEP.114.001943

14. Calkins H, Reynolds MR, Spector P, Sondhi M, Xu Y, Martin A, et al. Treatment of atrial fibrillation with antiarrhythmic drugs or radiofrequency ablation: two systematic literature reviews and meta-analyses. Circ Arrhythm Electrophysiol 2009; 2(4): 349-61. DOl: 10.1161/CIRCEP.108.824789

15. Ganesan AN, Shipp NJ, Brooks AG, Kuklik P, Lau DH, Lim HS, et al. Long-term outcomes of catheter ablation of atrial fibrillation: a systematic review and meta-analysis. J Am Heart Assoc 2013; 2(2): e004549. DOI: 10.1161/JAHA.112.004549

16. Cappato R, Calkins H, Chen SA, Davies W, lesaka Y, Kalman $\mathrm{J}$, et al. Updated worldwide survey on the methods, efficacy, and safety of catheter ablation for human atrial fibrillation. Circ Arrhythm Electrophysiol 2010; 3(1): 32-8. DOI: 10.1161/CIRCEP.109.859116 17. Deneke T, Jais P, Scaglione M, Schmitt R, DI Biase L, Christopoulos G, et al. Silent cerebral events/lesions related to atrial fibrillation ablation: a clinical review. J Cardiovasc Electrophysiol 2015; 26(4): 455. DOI: 10.1111/jce.12608

18. Cox JL, Boineau JP, Schuessler RB, Ferguson TB, Cain ME, Lindsay BD, et al. Successful surgical treatment of atrial fibrillation. Review and clinical update. JAMA 1991; 266(14): 1976-80. DOI: 10.1001/jama.1991.03470140088029 